\title{
Papers
}

\section{Are there two kinds of ward round?}

\author{
THURSTAN B BREWIN
}

The scene could be any medical or surgical ward anywhere. Discussion of an interesting diagnostic problem (out of earshot of the patients) is just coming to an end ...

CONSUltant : Are we agreed then ? The diagnosis is wide open, and we take no further action until we have the results of the various $x$-rays and so on. ... Now, it is getting late, who do we see next?

YOUNG DOCTOR (new to team): I think we can probably skip the next two cases, they are both terminal. There's really nothing anyone can do. The first is the 64-year-old man with widespread secondary carcinoma from an unknown primary, who has been blocking a bed for a month. He continues to deteriorate. The other man is 72 and ...

CONSULTANT (interrupting): Hold on a minute. If the first man you are talking about is George Reid, the plumber, it depends what you mean by "deteriorating." When I last saw him he was getting weaker, but we had had quite a lot of success with various symptoms and he was much happier. What's the present position?

YOUNG DOCTOR: The present position? Well, it has been known for some time that he has multiple liver and bone metastases. Shall I repeat his scans? They don't seem to have been done for over two months.

CONSULTANT (quietly, after a pause): Have you taken a history ? YoUNG DOCTOR (puzzled): Taken a history ? I don't understand ... I thought we were talking about Mr Reid.

CONSULTANT: We are. Each ward round we need you to tell us how he is getting on. Has there been any return of pain or shortness of breath ? Is his morale better, or worse, or about the same? If he has a new pain of a different type you will have to take an especially careful history. Does it arise from a bone metastasis or could there be some other cause? Has he any nausea? If so, is it due to his liver metastases ? to some drug we are giving him? perhaps to some needless fear or conflict that we might be able to resolve? With a differential diagnosis like that, repeating scans is about as much use as cold tea on a wet Sunday.

WARD SISTER: Perhaps I can help. He is still losing weight, and he is not quite so keen now to leave his bed to watch television with the others. But there has been no return of his original symptoms. In fact he has been joking with the nurses and is really in remarkably good form, especially since the horse he fancied came in second in the Derby and he won $£ 10$.

CONSULTANT: Good for him. ... I I must ask his advice sometimes ... (he turns to a 30-year-old doctor who has been with the team for two years). . . . Alan, we've got medical students coming tomorrow, haven't we? Could you take them? I suggest you first discuss the previous patient in detail, including all the investigations we are going to do. Then take them to George

Glasgow Institute of Radiotherapeutics and Oncology, Belvidere Hospital and Western Infirmary, Glasgow

THURSTAN B BREWIN, FRCP, FRCR, consultant
Reid. Tell them how we got his pain under control. Confess how slow we were to realise that his attacks of "shortness of breath" were due to hyperventilation. See how many of them remember the biochemistry of overbreathing. Remind them that this sometimes happens to people under stress. Point out that he has been free of attacks since we explained it all to him. Incidentally he had oral thrush, didn't he? Or was that another patient? Anyway, tell them it's a sign of professional incompetence to miss this in terminal patients.

WARD SISTER: Before we talk about the next patient could I ask you two questions about George Reid? Can he go for a short drive in his son's new car ?... Good. ... And could he see you alone for a minute some time?

CONSULTANT: Of course. Will 530 tomorrow be soon enough ? I'm afraid I'm very tied up till then. Now let's hear about the 72-year-old man you mentioned who has just come into the next bed. . . . Alan, you admitted him, tell us about him. Just a quick summary of the main points because it is getting late. A bit about his background and his job before he retired. How certain is the diagnosis and are we really sure it's terminal ? Then his symptoms. Are they all due to his malignant disease? Which of them worries him most? Do we need specialist help with any of them? Finally, the main points of your provisional plan for him....

Ten minutes later the ward round has seen George Reid and the new patient, who are now alone together.

GEORGE: Bill ? You know what I think ? I think there are two kinds of ward round.

BILL: How do you mean-two kinds?

GEORGE: I've been in five or six different hospital wards in the past two years-and a few more before that. I've talked to other patients. I've seen the difference. One kind of ward round is interested only in certain patients, the other is interested in every patient. When the first kind gets to someone like you or me, they either go straight on to the next patient-with maybe a quick nod if you're lucky - or they come and see you, but they do it in a quiet, awkward, switched-off sort of way. They don't really get to grips with any of your problems. It's almost as if, to them, you had ... how can I put it ... sort of died already, and it's all very sad, but there's no more to be said. So, of course, when they've gone, you feel even more depressed than you did before the ward round began. The other kind treats every patient as a real live person, until proved otherwise ... with opinions and feelings ... hopes and doubts ... good days and bad days ... maybe even a sense of humour. Take this ward round we have just had. $\mathrm{He}$ shook your hand as if he meant it, didn't he ? You got the feeling he was just as glad to see you as to see any other patient in the ward. He had heard about the boxing you did when you were in the Navy. Not like some wards where they seem to think you have been old all your life. Then he noticed your address-and asked you if it was true that the pub at the end of your road had changed hands. It didn't take a minute and it helped, 
didn't it ? You felt human-a person, not just a piece of the furniture-or, worse still, an embarrassment to everyone, like a bad smell in a clean ward. Last week he told me the story of the guide at Niagara Falls, who says, "I'll bet you have nothing like this where you come from," and the little man from Glasgow who replies "No, but I know a good plumber who might be able to fix it for you." I had heard it before, but I didn't have the heart to tell him so; he must have saved it up for the ward round, knowing I was a plumber. So that's the first thing you get on a good ward round. They treat you like a human being. And you begin to relax a little. And you feel less tense, more yourself. BILL: What's the second thing?

GEORGE: The second thing is that they want to know all about your symptoms. The ones that matter most to you are the ones that matter most to them. So far as possible, they aim to do something about them. There's nothing half hearted about it. You can see they mean business. They have a quick look at you, check up on a few things in a professional, workmanlike sort of way-maybe explain some of your symptoms-and then tell you what they are going to do and what they are hoping for.

BILL: Perhaps in some wards they just don't have the time. It's like any other job. You have to pick and choose a bit when you are under pressure.

GEORGE : No. It's not that. Take this lot we are with now. Every week they have a dozen new acute cases-sometimes they hardly know if they are coming or going. At times like that they can't spend more than a minute or two with patients like you and me. Even when they are not so busy, they forget things, they make mistakes, they are not perfect ... far from it. But they care. They try. They don't give up easily. When I came in I was in a terrible state, with pain and shortness of breath and God knows what else. I wanted to feel better quickly or die. And they saw this immediately. So they got to work. No messing about. No red tape. No waiting for scans or $x$-rays that weren't really needed. It took them less than two days to discover I needed four times the normal dose of morphine. That's quite common apparently. They asked me if I preferred tablets or liquid, and they explained that once the correct dose is found, then that's it-it doesn't usually lose its effect, and there's no need to increase the dose. Sometimes you can reduce it later on.

BILL: Maybe they think there's nothing they can do for some people and they'd just be wasting their time.

GEORGE: Well, if they think that, they have got it wrong, haven't they ? Any doctor who thinks that is only half a doctor. If a patient is really suffering a good doctor can always do something. I've seen it. Many times. Just taking an interest and trying something-anything-will help. And anyway a doctor's got to be sure that there isn't something crying out to be done that he didn't spot at first. I know that from my own job. You can't tell until you've weighed up a situation-and that takes a bit of skill and experience. You learn from your mistakes. You never stop learning. You enjoy life more if you approach all your work in that way-not just some of it. I get a lot of satisfaction from installing new bathrooms-that's my special interest and that's how I spend most of my time. But I'd be ashamed if I couldn't also make a good job of patching up a leak or unblocking a waste pipe for some old person living alone in a house soon due for demolition. And doing it quickly-no fuss, no frills, no unnecessary disturbance. A good plumber takes a pride in both kinds of work. He knows that either can be done well or done badly. I thought of that when the ward sister here got me unblocked last month. I never thought of a woman as a plumber, but she'd make a good one. I told her so. She did it gently, too. And what a difference it made ... you would never believe what a difference it made...

BILL: Maybe you should have been a doctor, not a plumber. GEORGE (smiling): Maybe I should . . . maybe I should . . . but I'm not complaining, I've had a good life . . . anyway, you'll be glad to hear that's the end of my lecture for today ... . so let's see if there's anything worth listening to on the radio, shall we ?

\section{Role of the hospice in the care of the dying}

\section{W D REES}

A hospice has three main roles and to these may be added various subsidiary roles. The three primary roles are to act as a catalyst, to provide a service to the community, and to serve as a centre for teaching. Of these, the catalytic action will be considered first.

\section{Catalytic action}

To place this role in perspective, you need to recall the general attitude to terminal care and bereavement 20 or even 15 years ago. Then the discussion of death and its wider implications was almost taboo. The terminal nature of an illness was rarely mentioned to the patient, and the usual practice of doctors and relatives was to hide from the patient the nature of any illness considered incurable. This applied especially to cancer. In the past 15 years the trend has been towards more open discussion about cancer and terminal illness. This trend is not complete but is developing rapidly. To assume that hospices are entirely

Paper read at Leicester General Hospital on 26 March 1982.

St Mary's Hospice, Selly Park, Birmingham

W D REES, MD, FRCGP, medical director or even mainly responsible for this change would be erroneous; but it is correct to claim that they played an important part in opening and enlarging the discussion on the subject. Theirs is the action of a catalyst, and this is a very potent factor. But catalysts work only when the other essential elements are present and do so by quickening a process that otherwise proceeds more slowly. The other needed factors are a readiness for people to change attitudes and accept open discussion on these important subjects. These factors are now present. People do feel an urgent need to give to death an interest and concern similar to that of birth. Hospices are an effective response and stimulus to that need.

\section{Care of the dying}

For the community it serves, the most obvious role of the hospice is the care of dying people. Some hospices provide inpatient care only, though increasingly other hospices provide both inpatient care and a home care service. The home care service is of increasing importance, but at present the inpatient care given by hospices makes more impact and receives the greater publicity. In discussing this aspect it is necessary to consider the various environments in which people die. In doing 